and he was put on the guaiacol treatment when the rash appeared. The case was a fairly severe one, the temperature being over $103^{\circ}$, but in two days it was all over and in two days more he was up and about the room as well as he ever was. Not only had he no bronchial catarrh (and he has already bad two attacks of broncho-pneumonia), but the catarrh which had so long troubled him disappeared and he emerged from the illness in better health than he has ever had.

The treatment seems to have no modifying effect on the measles itself, but it limits the case to measles and that alone without leaving any of the usual sequelæ. For vomiting, which rarely occurs, a little bismuth may be added to the guaiacol and to that again a little Dover's powder if required tor diarrhœa. The treatment is begun when the diagnosis is made and continued in full doses till the temperature bas fallen to normal, a reduced quantity being given for two days longer to make sure of the result. The dose is calculated at one drachm per diem in powders of ten grains every three hours for adults and children in proportion. The powder is readily taken by children and all the more so if an equal amount of powdered sugar is added. No un. favourable symptoms have ever been seen during its administration which could in the slightest degree be attributed to the treatment, in no case has it failed to abort the bronchial catarrh, and there have been no deaths.

Melbourne.

\section{A CASE OF OBSTINATE DYSPEPSIA FOLLOWED BY PERSISTENT HICCOUGH}

By JAMES Gilroy, M.B., C.M., L.F.P.S. GlasG.

ON Jan. 7th, 1903, I was called to a man, aged 50 years, suffering from severe vomiting and intolerance of food or drink. He told me that as he had not felt well he had gone to Harrogate for a change from here but that he returned much worse than when he left. I ordered poultices to be applied to the stomach, bismuth mixtures, hypodermic injections of morphia, ice to suck, and champagne at intervals. My attendance lasted until Jan. 28th and latterly the stomach-tube was used for lavage. The vomited material was at times quite black and for some eight to ten days I had great apprehensions owing to the supervening of a persistent hiccough. It seemed to defy everything. Hyoscyamus and ressure on the phrenic nerve gave only temporary relief. I found, however, that it was amenable at once to the ordinary doses of tincture of jaborandi with a litsle spirit of nitrous ether. Whether this points to a uræmic origin I must leave to others to decide. I can only say that the patient was never drowsy. Sleep was the one thing be could not get. Since the above date the patient has passed through a similar attack from Sept. 6th to Oct. 15th. He is now convalescent but the jaborandi again did excellent service in arresting hiccough.

Waterbeck, Dumfriesshire.

\section{NOTES OF A CASE OF PARALYSIS OF THE UPPER EXTRE UITIES, PROBABLY DUE TO DIPHTHERIA, ACCOMPANIED BY A RASH (SEPTIC).}

By R. E. P. SquibBS, M.R.C.S. ENG., L.R.C.P. LoND.

THe patient was a girl, aged three and a half years, and was first seen by me on August 7th, 1903. She had always enjoyed fairly good health and the family history was good but she had lost two brotbers in infancy. Three weeks before the present seizure she had returned from the seaside and had appeared to be well up to August 4th, but on questioning the mother I found that the child had seemed different from usual and slightly ailing. She was said to have fallen on Aupust 5 th as if in a fainting fit. Her condition on the 7th was as follows. She was unable to move her upper limbs, the left arm being even more helpless than the right and the first to be affected. The temperature in the axilla was $998^{c} \mathrm{~F}$. The child was slightly sick. Her skin was moist and flunhed. I gdve her some sodium salicylate and ordered the joints to be wrapped in cottonwool, on which some castor oil was to be poured. On the 8th the temperature in the axilla was $100^{\circ}$. There was no power of movement in the upper limbs but sensation seemed to be unaffected. The child had passed a restless night and there was a well-marked flush upon the chest. An enema was given as the bowels were confined. On the 9th the temperature in the axilla was lower. There seemed to be more ability to move the arms. There was a well-marked scarlatiniform rash over the chest and abdomen. On the 11th there was a wellmarked scarlatiniform rash over the chest, back, arms, and thighs. There was no sore throat. There were much restlessness and sleeplessness and the bowels were constipated. The patient took a fair amount of liquid nourishment; she cried out if her arms were moved but she could move the fingers of the right hand. I gave small doses of bromide of potassium. On the 18th the rash had disa ppeared and the patient felt better. Both arms were still paralysed and attempted movement caused her to cry out. The right arm was improving. On the 24 th the patient had much improved except for the paralysis of the left arm and paresis of the right arm, though she could move the fingers and wrist. This day I met in consultation Dr. Lewis W. Marshall who formed the opinion that this was a case of neuritis following diphtheria, the rash being of a septic nature. He also recommended the use of strychnine and iron in small doses. By Oct. 16th, using electricity and tonics, I had succeeded in a great measure in restoring the power of the right upper limb but I regret to say that the left arm is almost completely useless, as the patient is only able slightly to move the wrist and the fingers.

Nottingham.

\section{9 atirtor}

\section{HOSPITAL PRACTICE, BRITISH AND FOREIGN.}

Nulla autem est alia pro certo noscendi via, nisi quamplurimas et morborum et dissectionum historias, tum aliorum tum proprias collectas habere, et inter se comparare.-MorgaGNI De Sed. et Caus. Morb. lib. iv., Pronmium.

\section{MANCHESTER ROYAL INFIRMARY.}

\section{PSEUDO (?) ANGINA PECTORIS OCCURRING IN CASES OF} MITRAL STENOSIS.

(Under the care of Dr. Graham Steell.)

THE two following cases have been under observation from time to time at the Manchester Royal Infirmary for several years. For the notes of them now published we are indebted to Dr. M. Stanley Wood, house physician.

CASE 1 -This patient is a woman, 22 years of age. She had attacks of rheumatic fever at five years of age, at 15 years, and again at 19 years. She of ten suffered from " pains in the joints and sore throat" as a child and has been "short of breath" on exertion as long as she can remember. She had "swelling of the feet" during the last rheumatic attack and several times since. On auscultation a very constant presystolic murmur is heard at the apex of the heart. The history of her anginal attacks is as follows. She first complained of pain in the " region of the heart" at 11 years of age. She has had pain somewhat frequently since that time but only in the region of the heart until five montbs ago, when the pain commenced to shoot up to the leit shoulder and then down the arm on the left side. One month ago the pain commenced to shoot up to the left side of the neck and face. She has not been quite free from "pain round the heart "for two months. The leading features of an anginal attack are as follows. The pain usually begins from 7 to 9 P.M. ; it comes on gradually and is preceded by an attack of dyspnœa. It first commences in the region of the heart and is described by the patient as "cramp of the heart." This pain gradually a-sumes more of a "dragging" character than one of constriction; at the same time "shooting, tingling" pains begin to pass to the left shoulder and down the left arm, sometimes to the. elbow only, sometimes to the ring finger and little finger. The right shoulder and arm have never been affected. During recent attacks the pain has also passed up to the left side of the neck and face, the pain here being similar to that in the arm, of a "shooting, 